\title{
The Influence of U.S. Legal Education on South Korean Legal Education
}

\author{
Jaewan Moon ${ }^{1}$
}

\section{Introduction}

Modern legal education system in South Korea was heavily influenced by Japan and Germany. Japan had adopted the German legal system during the Meiji Restoration and transplanted it to Korea during the Japanese colonial period ${ }^{2}$. Even after Korea's liberation from Japan in 1945, Japanese influence was still prevalent in the content and the structure of legal education ${ }^{3}$. With the emergence of need for reforms in the legal education as a social issue in 1990s, the influence of the U.S. legal education as an aspirational model rapidly increased. Its influence reached a peak when the U.S.-influenced law school system was established in March 2009. During the same time period there were also active discussions on globalization of the legal market ${ }^{4}$. In Korea there were also significant interests in the issues related to American ${ }^{5}$ law firms domination in the global legal market and the education and training systems American practitioners undergo.

\footnotetext{
${ }^{1}$ Professor and Former Dean, Law School, Hankuk University of Foreign Studies in Seoul, Korea. He expresses his gratitude that Professor Maggie Kim of Law School, Hankuk University of Foreign Studies, greatly contributed to this paper.

${ }^{2}$ Neil Chisholm, The Faces of Judicial Independence: Democratic Versus Bureaucratic Accountability in Judicial Selection, Training, and Promotion in South Korea and Taiwan, 62 Am. J. Comp. L. 893 (2014).

${ }^{3}$ J. MURPHY, LEGAL EDUCATION IN A DEVELOPING NATION: THE KOREAN EXPERIECE 65 (Seoul National Univ. Press \& Oceana Publications, 1967).

${ }^{4}$ Korea opened up its legal service market in September 26, 2009. See Jaewan Moon, Impact of Globalization on Legal Profession, HUFS Global Law Review Vol. 4 No. 2 (August 2012).

${ }^{5}$ The term American and U.S. has been used interchangeably in this paper.
} 


\section{Before the Adoption of Law School}

\section{American Law School as an Ideal Legal Education Model}

Many legal activists in Korea thought of the American law school model as an ideal system for Korean legal education. It seemed like a 'magic wand' that could solve all problems in Korean jurisprudence and legal community. Every time the legal education reform was discussed, the adoption of the American law school model was regularly brought up as a possible alternative.

Prior to establishment of the current law school system and the bar exam, selection of legal professionals was accomplished through National Judicial Exam ("NJE"). And the Judicial Research and Training Institute ( "JRTI") was established in January 1971 under the supervision of the judiciary branch to be responsible for the training of those who had successfully passed the judicial exam. NJE was a competitive exam ${ }^{6}$. It required no formal legal education as pre-qualification to taking the exam and the number of successful applicants were pre-determined by Ministry of Justice. Passing the exam was like a token guaranteeing future with wealth and honor and the scores obtained in the judicial exam were treated as if the applicant's legal ability was officially approved by the state.

Such limited number as well as prevalent Confucius belief which considered public service as prestigious ${ }^{7}$ brought about situation where the passers of NJE were conferred relatively high rank within the government and were given salaries from the government while they participated in the training course. Those who passed NJE and attended JRTI seemed to have a common mindset that they are the privileged.

But as Korean economy developed and society became more diversified and globalized, JRTI's teachings which mainly focused on litigation revealed limitations in training lawyers' capability to deal with

\footnotetext{
${ }^{6}$ NJE had existed from 1963 to 2017 . The average passing rate during the entire period is $2.93 \%$ (20, 609 passers out of 702.513 applicants). For more information on NJE before introduction of law school in Korea, see Chang Rok Kim, The National Bar Examination in Korea, 24 Wis. Int'1 L.J. 243 (2006).

${ }^{7}$ For Confucius culture in Korean education see Jasper Kim, Socrates $v$. Confucius: An Analysis of South Korea's Implementation of the American Law School Model, 10 Asian-Pac. L. \& Pol'y J. 322, 347 49 (2009).
} 
complicated legal disputes professionally and effectively. American law schools emerged as possible alternative to solve the issues that were identified in the legal education and training systems, and also as a path to improving the international competitiveness of Korean lawyers. In 1995, the Globalization Committee, established by President Kim Young-sam, proposed the adoption of the American law school model as a part of the judicial reform. After much debate, the American law school model was still not introduced but the judicial exam passage number increased from 300 to 1,000 .

\section{Internal and External Factors that Make the U.S. Law Education Ideal}

In order to understand why the American law school is considered as an ideal model for Korea, one should look at the environment of law education up to such adoption. It was JRTI that has the responsibility to educate lawyers. College level legal education was departed from educating lawyers.

However there was awareness in legal academia that it was not possible to nurture legal professionals suited for globalized and diversified society under such system. Globalization is definitely one of the major factor that contributed to the increasing appreciation of U.S. legal education system. As the Korean economy increased in size, so did the demand for more developed legal services. Especially in the 2000s, as the issue of opening up the legal market to foreign law firms came to the forefront, the improvement of lawyers' global competitiveness was a new challenge that the Korean legal community faced. Large law firms attempted to tackle this issue and ran programs to prepare for globalization ${ }^{8}$. One of the ways was by sending their lawyers to American law schools to acquire LL.Ms and allowing them take practical training in U.S. law firms for six months to a year'.

\footnotetext{
${ }^{8}$ Neil Chisholm, Legal Diffusion and the Legal Profession: An Analysis of the Processes of American Influence on South Korea's Lawyers, 26 Colum. J. Asian L. 267 (2013).

${ }^{9}$ Carole Silver, Jae-Hyup Lee \& Jeeyoon Park, What Firms Want: Investigating Globalization's Influence on the Market for Lawyers in Korea, 28 Colum. J. Asian L. 1 (2014).
} 


\section{Adoption of Law Schools}

\section{Influence of the American Law School}

Korean law school system in many aspects adopts that of the United States. Like the American law schools it is 3 years long post baccalaureate professional school, and like most states in America only the graduates of law schools are allowed to take the bar exam ${ }^{10}$. And like the U.S. there is no requirement of practical training after passing the bar exam ${ }^{11}$. And akin to the American legal education system, the ratio of professor to students is low. Ethics and professional skill classes are included in law school curriculum.

\section{Differences from American Law School}

Though Korean law school is similar to the American law school in form, there are many differences in its content. One crucial difference lies in the relationship between the bar exam and legal education. Korea has a long history of selection of high ranking public officials through examinations ${ }^{12}$. Same attitude applies to the bar exams. The passing of bar exam is deemed as absolute measure of quality of legal ability in Korea unlike the U.S. where it verifies only a qualification to act as a lawyer. In Korea, the number of passers are determined each year by the Minister of Justice after hearing opinions from the Supreme Court, the Korean Bar Association and the Korean Association of Law Schools ${ }^{13}$. This differs significantly from the United States. The Code of Recommended Standards of Bar Examiners ${ }^{14}$, clearly states that the purpose of the bar

\footnotetext{
${ }^{10}$ ABA Standards \& Rules of Procedure for Approval of Law Schools (20192020), Chapter 3 sets out clear perimeters of such matters as objective and curriculum of a $\mathrm{ABA}$ requirements along with other matters.

${ }^{11}$ It should be noted there has been greater emphasis on practical training of law school in recent years. Some states require testing of practical skill as part of their bar exams.

${ }^{12}$ The national civil service examination called 'Gwageo' was established in 958 and maintained its position as the only entrance to high ranking public officials during the Joseon dynasty.

${ }_{13}$ National Bar Examination Act(Act No. 9747, May 28, 2009 Amended by Act No. 10923, Jul. 25, 2011 Act No. 15154, Dec. 12, 2017), Article 10 (1).

${ }^{14}$ Code of Recommended Standard for Bar Examiner recommends to all the
} 
exam is "not to limit the number of lawyers admitted to practice.". In this scheme law school education becomes subservient to the bar exam. In turn school education inevitably becomes centered on the subjects included in the bar exam.

\section{10 Years After the Adoption of Law School System}

\section{Education System}

The year 2019 marked the 10th anniversary of the commencement of the law school format. Evaluations after ten years are generally positive. In the interim there have been attempts to uproot the basic framework of law school system, but fortunately, the law school system has managed to remain intact as it had been established. Following are a few positions that support changes to the law school system.

First is the position supporting the retention of the judicial exam. NJE had existed until 2017. However, there has been continuing assertions that the system producing lawyers through NJE should be maintained. A constitutional complaint was filed asserting that abolition of the judicial exam was unconstitutional. The Constitutional Court decided on September 29, 2016, that the abolition of the judicial exam was not unconstitutional ${ }^{15}$.

Second is the position supporting enactment of the preliminary exam, which supported the idea of maintaining the framework of NJE under the law school system. The preliminary exam advocates asserts that the person who passed the preliminary exam be allowed a waiver to the requirement of a law scool graduate and be allowed to take the bar exam. The fact that Japan operates a preliminary exam system is a major basis supporting such argument. This issue is still unsettled.

national governing bodies of the respective states that the "bar exams should test the ability of the applicant to identify legal issues $\cdots$ and to arrive a logical solution by application of legal principles, in a manner which demonstrates a thorough understanding of these principles...", Comprehensive Guide to Bar Admission Requirements, National Conference of Bar Examiners and ABA Section of Legal Education and Admissions to the Bar (2019), ix

${ }^{15}$ Constitutional Court Judgment of Sep. 29, 2016, 2012Hun-Ma1002, 28-2 KCCR 477. 
Third is a recently rising claim for online law school run by Korea National Open University. Currently ruling Democratic Party of Korea, which won supermajority in 2020 election, announced the plan of introducing online law school before the election ${ }^{16}$. However, the prospect of such law school is not promising due to strong opposition from both the Korean Bar Association and the Korean Association of Law Schools.

\section{Education Contents}

\section{(1) Merits and Demerits of Law School Education}

One of the positive development as a result of establishment of law schools is that the original purpose of cultivating legal professionals through legal education has been realized to some extent ${ }^{17}$. Since graduating from an approved law school is a requirement to take the bar exam, law school education is linked to the selection of legal professionals. However this gave rise to a new problem that made legal education overly linked and even subordinated to the bar exam. As the passing rate of the bar exam become year by year lowered given the cap existing for number of applicants passing the bar, only lectures in subjects that help prepare for the bar exam are opened, and the other lectures are closed due to lack of students' participation. The passing rate of the bar exam has dropped from $87.15 \%$ in the first exam in 2012 to $49.35 \%$ in $2018^{18}$.

It is difficult to say whether the law school system is successful in diversifying the content of legal education. The law school system was introduced with the idea of preparing for the globalization, but with the

\footnotetext{
${ }^{16}$ Ahn Hye Sung, Minjudang, 'Bangtongdae Yagan Lawschool Doip' Chongsun Gongyak Gesi [Democratic Party of Korea Made a Campaign Promise to Introduce Online and Night Law School], Bubryul Journal [The Law Journal], March 11, 2020.

${ }^{17}$ Lee Jae Hyup, Rhee June Woonge, Hwang Jung Hyun, Lawschool Chulsin Bubryulga, Geudeulen Nuguinga? [Law School Lawyers in Korea, Who Are They?], Seoul Law Journal Vol. 56 No. 2 p 406 (June 2015); Moon Jaewan, Bubhak Gyoyukgwa Bubhakgeonmundaehakwon [Legal Education and Law School] in HANKUK BUBHAKGWA BUBHAKGEONMUNDAEHAKWON [LEGAL EDUCATION AND LAW SCHOOL IN KOREA] pp 80 89 (2018).

${ }^{18}$ The passing rate has slightly increased last two years against the strong opposition from the Korean Bar Association. The rate is 50.78\% in 2019 and $53.3 \%$ in 2020 . However, it is not expected to keep going up considering worsening legal service market.
} 
current system that solely emphasizes the bar passing rate this has been proven to be difficult to achieve ${ }^{19}$.

\section{(2) American Influence in Law School Education}

There is little room for American legal education to influence substantive legal education in law schools. There are many assertions that law school education should focus on cultivating the ability to identify issues and solve problems as they do in the United States ${ }^{20}$ rather than just delivering specific legal information but the reality faced by law school does not allow such teachings. The law school classes are subordinate to the bar exam, and the bar exam is mostly structured to assess whether he/she knows the content of the specific cases ${ }^{21}$. A study showed that law school students need to memorize as many as 10,000 court cases to prepare the bar ${ }^{22}$.

On the other hand, practical education is influenced considerably by U.S. legal education. Practical education in areas such as legal ethics, legal research, drafting legal documents, mock trials, and legal clinics are provided similar to the American law schools' courses. Now legal ethics is mandatory for all law schools, and the applicants must pass a separate legal ethics exam in addition to the bar exam ${ }^{23}$.

${ }^{19}$ See Young-Cheol K. Jeong, Korean Legal Education for the Age of Professionalism: Suggestions for More Concerted Curricula, 5 E. Asia L. Rev. 155 (2010); Jaewan Moon, How to Change Law School Education in an Age of Oversupply of Lawyers, HUFS Global Law Review Vol. 8 No. 1 (2016).

${ }^{20}$ Important point of note however is that on May 17, 2019 the Council of the ABA Section of Legal Education and Admission to the Bar approved of major change in the bar passage standard. The newly approved Standard 316 requires that 75 percent of the law school graduates who sit for the bar pass it within two years. The Council is recognized by the Department of Education as national accreditor of law school and has the final say on the accreditation of law schools. It will be interesting to see where this leads as this seems to be an attempt to link legal education to outcome based performance scale of passing the bar. Standard 2019-2020 Standard 316.

${ }^{21}$ According to a research paper conducted by 17 professors of the Seoul National University Law School in May of 2018, the reason for not being able to meet the goals of law school system at the time of its introduction is mostly due to excessively difficult and competitive bar exam.

${ }^{22}$ Lee Jae-Min, After 10 Years, Legal Education Reform at Its Crossroads, The Korea Herald, Nov. 27, 2018. 


\section{Education Method}

There are two main methods of teaching in law schools. One is the lecture format and the other is the writing correction format that was typical in JRTI. Generally, the former is used for theoretical courses and the latter is used for practice classes. The lecture type is a way for the professor to introduce the theory and the contents of recent cases. At the beginning some law school professors tried the Socratic method of education as offered in the American law school. However, unlike the United States, in Korea, the Confucian culture which respects hierarchy inhibits the process and it is difficult for students to discuss on equal standing with the professor in the classroom ${ }^{24}$. Moreover, due to the pressure of the bar exam, students take lectures helpful to pass the exam.

\section{Educators}

The composition of full-time faculty members of law school has been influenced by the American model. In the past, there were about 10 fulltime professors on average in each college of law. Most of them earned doctorate degrees from the countries with continental law systems or domestic universities. There were few professors with practical experience.

The current law mandates employment of at least 20 full-time professors at each law $\operatorname{school}^{25}$. More than $20 \%$ of the faculty is required to be professors with at least five years of practical legal experience ${ }^{26}$. At the time of the introduction of the law school, competition for accreditation was fierce, and all the schools had many more than 20 professors. It is also noteworthy that the number of practitioners who enter the academic world has significantly increased. The recent recruitment pattern of law school professors shows preference for doctoral degree holders with practical experiences rather than doctoral degree holders without a license to

\footnotetext{
${ }^{23}$ Speaking accurately, the National Bar Examination consists of a written examination with multiple-choice questions, essays, and a separate Legal Ethics Examination. National Bar Examination Act, Article 8 (1).

${ }^{24}$ Jasper Kim, Socrates v. Confucius: An Analysis of South Korea's Implementation of the American Law School Model, 10 Asian-Pac. L. \& Pol'y J. 322, 347 49 (2009).

${ }^{25}$ Act on Establishment and Management of Professional Law Schools, Article 16 (3).

${ }^{26} I d$. at Article 16 (4).
} 
practice law.

\section{Outlook}

\section{Education System}

There are still many people who have nostalgia for the past, but the law school framework has been established firmly enough simply not to revert to the past. The discussion on improving the law school system will be on going. The issues of raising the bar exam passing rate and amending the contents of the exam suitable for the 21 st century will be continuously discussed. The mile marker in this discussion is the American bar exam. However, it should be kept in mind when pursuing this line of discussion that average passing rate in U.S. is currently little less than $62 \%$, which is not that much higher than current passing rate in Korea of 53\%. The more important distinction is that US bar exam is not intended purely to limit the number of practitioners to certain number. Although respective states have different standards generally a candidate passes the bar if he/she meet a certain standard, not if his/her score is within a certain percentile. Of course this doesn't address the larger issue that the bar passing rate should not be used as sole measure of a law school's quality.

The average amount of lawyers' salaries and social status have been lowered due to the surge in the number of lawyers since the establishment of the law school. This will inevitably lead to a revision of the law school system. Still, lots of students want to enter the law school. The number of applicants for legal aptitude test, which is necessary for law school admission, is 10,291 in 2019, which is the largest since 2008, the first year which had 9,690 applicants.

\section{Education Contents}

The argument that the legal education in the law school should be liberated from the bar exam is a strong one. Such separation is not likely to become reality. Because the traditional approach of measuring capability through the exam dominates the Korean legal profession, the bar exam is likely to take the form of assessing current legal knowledge as an indicator of success in the future. There is a social demand for creativity in solving new types of legal conflict, but it is unlikely that the law school education will change in response to this demand. What the legal circle demands of 
the law school are education faithful to the fundamentals of law. The impact of U.S. legal education on Korea is very limited in the current situation where legal education is subservient to the bar exam.

\section{Education Methods}

Unless the bar exam changes, it will be difficult to change current education method. It is very unlikely that the Socratic method of American law school will become popular in Korea. Although there is still interest in legal clinic education, there is no possibility that it will become much more active unless the heavy burden of the bar exam is lightened ${ }^{27}$.

Legal education is an evolving subject that needs to meet societal changes, Korea like other countries will continue discussing how to improve its legal education. And most likely under the current climate efforts to restructure law schools modeling the U.S. legal education system will still be most influential.

\footnotetext{
${ }^{27}$ It is noteworthy that the SNU law scool, a leading law scool in Korea, hired 6 clinical law professors in various fields on March 1, 2020. However, it is wait and see whether clinical education will expand to other law scools.
} 